\title{
81 当科における縦隔に波及した深頸部膿瘍症例の検討
}

○寶地信介、橋田光一、大久保淳一、大淵豊明、池菩祥司、鈴木秀明

産業医科大学 医学部 耳鼻咽喉科

今回われわれは過去 12 年間で、当科で入院加療を行った降下性縦隔炎合併例を含む深頸部膿瘍症例について臨床的に検討 した。検討項目として深頸部膿瘍単独群（頸部群）と縦隔まで波及した群（縦隔群）で、年齢、基礎疾患、入院期間、検査 所見、治療内容、起炎菌などについて比較検討した。縦隔群は頸部群に比べて、炎症反応が著明に高值で、入院期間が延長 し、気管切開術を施行した症例も高率であった。また縱隔群では高頻度にStreptococcus milleri group が検出され、媣頸部 膿瘍における同菌の重症化因子としての関与が示唆された。全症例を糖尿病の有無で比較検討すると糖尿病を有する患者群 の方が、有意に血液検査上の炎症反応が高く、入院期間は延長し、縦隔炎の合併や気管切開症例も多くみられた。従来から の指摘通り糖尿病は深頸部膿瘍に押ける重症化、遷延化の重要な要因と考えられた。

\section{Rhodococcus による頸部膿瘍の 1 例}

○本間那奈、秋山理央、谷 康寛、鈴木美雪、杉尾雄一郎、杉内智子、調所廣之 関東労災病院 耳鼻咽㑨科

症例は79歳女性、頸部腫脹を主訴に来院し、頸部造影 CTにて舌根部から右顎下部にかけて膿瘍形成を認めた。抗菌薬の 点滴を開始したが、症状の悪化を認めたため、第 2 病日に気管切開術、頸部膿瘍切開排膿術を行い、術後連日ドレーンより 洗浄を行った。細菌結果はRhodococcusであり、起因菌と判断し、RFP、CLDM の内服を 1 力月継続し、膿瘍の消失を認め た。Rhodococcus equi は仔馬の化膿性肺炎の原因菌として1923年に初めて記載され、到死率の高い幼馬感染症の起因菌とし て知られている。ヒトへの感染としては、1980年代初頭にHIV 流行によって急増した。馬を含めた草食動物の粪便から分 離され、それらの暴露によって感染するが、本症例では、動物や農地土壤の暴露歴はなく、免疫正常者であった。免疫正常 者の同菌による頸部膿瘍の症例は本邦では報告がない。抗菌薬療法を的確にすすめるためには、確実に菌の同定を行い、起 因菌同定に基づいた抗菌薬療法を行うべきと考えられた。

\section{3 当初咽後膿瘍が疑われた石灰沈着性頸長筋腱炎の一例}

○代田桂一、柘植勇人、寺田聡広、鈴木啓介、西川大輔、稲垣憲彦

名古屋第一赤十字病院 耳鼻咽喉科

石灰沈着性頸長筋腱炎は、頸長筋腱への石灰沈着による急性炎症である。急激に頸部痛、讌下痛を発症するが通常 $1 、 2$ 週間で改善する。今回われわれは咽後膿瘍疑いにて紹介された石灰沈着性頸長筋腱炎を経験したので報告する。症例は 27 歳、女性。前日朝起床時より後頸部痛を自覚。徐々に痛みが増悪し 2 日後に当院整形外科を受診され、頸部 Xp にて咽頭後 壁の肥厚を指摘された。血液検査上 CRP 0.5 WBC 9500 であった。同日当院耳鼻科に紹介されるが、視診上は咽頭壁の腫 脹は認めず経過観察となった。翌日症状の増悪があり整形外科再診し、MRI T2 強調画像にて、椎体前面に高信号を呈する 病変を認め咽後膿瘍疑いとして当科へ再度紹介され、入院加療となった。入院翌日の頸部 CT で軸椎前面に石灰化を認めた ため、石灰沈着性頸長筋腱炎と診断した。消炎鎮痛剂での対処療法にて疼痛は徐々に改善し、入院 7 日後に退院された。咽 頭後壁の腫脹と頸部痛を来し、咽後膿瘍としては非典型的な症例には本疾患を鑑別に挙げる必要がある。診断には CT 検査 での軸椎前面の石灰化所見が有用である。

\section{4 小児 Auditory Neuropathy における OTOF 遺伝子の遺伝子型と表現型の相関}

$\bigcirc$ 松永達雄 ${ }^{1}$ 、守本倫子 ${ }^{2)}$ 、新正由紀子 ${ }^{11}$ 、有本友季子 ${ }^{3)}$ 、片岡祐子 ${ }^{4)}$ 、岡本康秀 ${ }^{5)}$ 、新田清 ${ }^{6)}$ 、新谷朋子 ${ }^{7)}$ 森田訓子 ${ }^{8)}$ 、杉内智子 ${ }^{9}$ 、増田佐和子 ${ }^{10)}$ 、仲野敦子 ${ }^{3)}$ 、泰地秀信 ${ }^{2}$ 、加我君孝 ${ }^{1)}$

国立病院機構 東京医療センター 感鸴器センター ${ }^{12}$ 、国立成育医療研究センター 耳鼻咽喉科 ${ }^{2}$ 千葉県こども病院 耳鼻咽喉科 ${ }^{3}$ 、岡山大学 医学部 耳鼻咽喉科 ${ }^{4}$ 、稲城市立病院 耳鼻咽喉科 ${ }^{5}$ 済生会宇都宮病院 耳鼻咽喉科 ${ }^{6}$ 、札幌医科大学 医学部 耳鼻咽喉科 ${ }^{7}$ 、帝京大学 医学部 耳鼻咽嗋科 ${ }^{8}$ 関東労災病院 耳鼻咽喉科 ${ }^{9}$ 、国立病院機構 三重病院 耳鼻咽喉科 ${ }^{10}$

Auditory Neuropathy (AN) はABR で無反応か高度異常を呈するが OAEでは正常である難聴であり、言語聴取能が著し く低い特徵を持つ。また、本難聴では ABR、ASSR などの他覚的聴力検査結果が実際の聴覚レベルに相関せず、これは乳幼 児の言語聴覚ハビリテーションに打いて特に問題となる。われわれは難聴の危険因子がない日本人小児 AN では、その多く が OTOF 遺伝子変異が原因であることを示してきた。本研究では、小児 AN 23例において OTOF 遺伝子の遺伝子型から表 現型（難聴の特徴）を予測できるかについて検討した。この結果、日本人の最多ミスセンス変異とナンセンス変異、フレー ムシフト変異、スプライス変異を 2 アレル持つ場合は高度あるいは重度難聴を呈し、上記以外のミスセンス変異、ストップ コドン変異を持つ場合は軽度あるいは中等度難聴を呈した。この結果から小児 AN に対する OTOF 遺伝子検査では聴力レ ベルをある程度推測可能で、言語聴覚ハビリテーションに役立つ場合があると考えられた。 
85 日本人高度感音難聴患者における OTOF 遺伝子変異の頻度の検討

○岩佐陽一郎 ${ }^{1} 、$ 吉村豪兼 ${ }^{1)} 、$ 宇佐美真一 ${ }^{1)}$ 、神田幸彦 ${ }^{2}$ 、熊川孝三 ${ }^{3)}$

信州大学 医学部 耳鼻咽喉科 ${ }^{1} 、$ 萌悠会 耳鼻咽喉科＼cjkstart神田 $\mathrm{E} ・ \mathrm{~N} ・ \mathrm{~T}$ 医院・長崎ベルヒアリングセンター ${ }^{2}$ 、

虎の門病院耳鼻咽喉科＼cjkstart聴覚センター ${ }^{3)}$

OTOF 遺伝子は非症候群性 Auditory neuropathy spectrum disorderの原因として同定された遺伝子であり、先天性高度感 音難聴を呈する例が大部分である。非症候群性難聴患者において最も高頻度に認められる遺伝子として GJB2 が挙げられる が、海外においてはそれに次ぐものとして SLC26A4、MYO15A、CDH23、TMC1などとともにOTOF 遺伝子が重要視され ている。しかし、本邦における OTOF 遺伝子変異の頻度の検討については未だなされていないのが現状である。今回われ われは、信州大学耳鼻咽喉科が管理する日本人難聴患者遺伝子データベースより高度〜重度難聴、孤発例もしくは劣性遺伝 形式をとる先天性難聴患者103名（ただし、GJB2、SLC26A4、1555A > GミトコンドリアDNA 変異と診断されているもの は除く) に対し、直接シークエンス法を用いて OTOF 遺伝子変異の解析を行い、日本人難聴患者における頻度の検討を行 ったので報告する。

\section{6 ミトコンドリア tRNA 遺伝子 T7511C 変異による非症候性難聴を示す 1 家系}

○渡部高久 ${ }^{1)}$ 、松永達雄 ${ }^{2}$ 、佐藤美奈子 ${ }^{3)}$ 、小川 郁 ${ }^{11}$

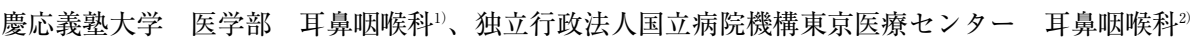

東京電力病院 耳鼻咽喉科 ${ }^{3}$

難聴と関連するミトコンドリア遺伝子変異は数種類知られており、非症候性難聴の原因にもなる。今回、母系 4 世代に渡 る非症候性難聴を示す家系で、ミトコンドリア tRNA 遺伝子の T7511C ホモプラスミー変異を確認した。遺伝子解析をした 5 人すべてから変異を認めた。内 4 人は難聴を認めたが、成人発端者の妹は聴力正常であった。聴力型は水平型や高音漸傾 型、低音障害型であり、重症度は軽度から中等度、発症年齢は先天性あるいは乳幼児期が疑われたが、学童期、思春期、成 人後の発症例もあった。過去のアフリカンアメリカン 2 家系、フランス 2 家系、日本 1 家系でも臨床型は家系内で様々であ るが、他家系で認める様な重度難聴例は認められていない。また、他の変異を伴うアフリカンアメリカン 2 家系に比して、 浸透率が低い。本変異に影響する他因子の存在が考慮され検討が必要である。

\section{7 先天性高度感音難聴小児例における MYO7A 遺伝子解析}

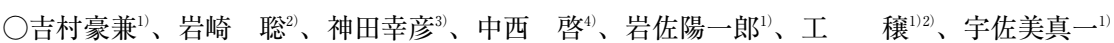

信州大学 医学部 耳鼻咽喉科 ${ }^{1)}$ 、信州大学医学部附属病院 人工聴覚器講座 ${ }^{2} 、$

(医) 萌悠会 耳鼻咽喉科 神田 $\mathrm{E} \cdot \mathrm{N} \cdot \mathrm{T}$ 医院、長崎ベルヒアリングセンター ${ }^{3} 、$ 浜松医科大学 耳鼻咽喉科 ${ }^{4}$

Usher 症候群は感音難聴に網膜色素変性症を伴う疾患の代表であり、その中でもタイプ 1 は先天性高度感音難聴に前庭機 能障害を伴い、さらに10歳前後に視覚症状が生じるという最も重篤な表現型を呈する。近年補聴器や人工内耳の発達により 聴覚活用が可能となってきており、遺伝子検査による早期診断が治療や療育において重要な情報となる可能性がある。そこ でわれわれは視覚症状が出現していないと予想される先天性高度感音難聴小児例を対象に、タイプ1の原因遺伝子で最も頻 度が高いとされる MYO7A 遺伝子変異の解析を行ったので報告する。

\section{TECTA 遺伝子変異が同定された優性遺伝高音急墜型難聴家系}

○石川浩太郎 ${ }^{1)}$ 、岩佐陽一郎 ${ }^{2)}$ 、茂木英明 ${ }^{2)}$ 、宇佐美真一 ${ }^{2)}$ 、市村恵一 ${ }^{1}$

自治医科大学 医学部 耳鼻咽喉科 ${ }^{1)}$ 、信州大学 医学部 耳鼻咽喉科 ${ }^{2}$

現在では先天性難聴の遺伝子診断が先進医療として認められるなど、日常診療に遺伝性難聴が深くかかわりを持つように なった。今回、われわれは高音急墜型難聴を示す優性遺伝形式遺伝性難聴家系の遺伝子解析を行い、TECTA 遺伝子変異を 同定した。TECTA 遺伝子は常染色体優性または劣性遺伝形式の非症候群性遺伝性難聴の原因遺伝子として知られ、蓋膜の 非コラーゲン基質を構成する $\alpha$-tectorin をコードする遺伝子である。今回、同定された変異部位は、ヒトからゼブラフィッ シュまで高度に保存されている。また、この変異は TECTA 遺伝子 ZA ドメインの TIL-2 領域に存在している。 TIL-2 領域 は10個のシステインがジスルフィド結合を作って構造を形成するのに重要なドメインであり、加えて今回の変異が塩基性ア ミノ酸から中性への変化のため、折りたたみ構造を阻害する可能性が示唆される。さらに過去の報告から ZA ドメインの変 異で優性遺伝形式の高音急墜型難聴を呈する家系が報告されており、以上から原因遺伝子として有力と考えられる。 
○鈴木伸嘉、宇佐美真一

信州大学 医学部 耳鼻咽喉科

【目的】

老人性難聴は個人ごとに難聴の程度が様々であり、多因子疾患であると考えられている。老人性難聴の遺伝的要因の一つ として SNPがいくつか報告されている。今回、われわれの日本人サンプルを用いてこれらの SNPを再評価した。

【方法】

45歳以上の日本人706サンプルを用いた。今までに報告されている老人性難聴関連 SNP である 9 遺伝子中の $19 \mathrm{SNP} に つ$ いての関連性に関して評価を行った。

【結果㧍よび考察】

国外における報告のSNP を検証したが、われわれのサンプルでは有意に関連があるとの結論は得られなかった。これら の施設で対象としたサンプルはコーカソイドが主なものであり、老人性難聴に関連する SNP は人種ごとに異なっているこ とが示唆された。また、国内からの報告で関連があるとされたSNPに関しても、有意差を持った関連はなかった。患者の 背景、基礎疾患などの外的要因の影響があると考えられた。(本研究は信州大学医学部熟年体育大学遺伝子解析コンソーシ アムおよびアントワープ大学 Dr. Guy van Camp との共同研究として行われた。)

\title{
90 GJB2 遺伝子変異の遺伝子型と表現型の相関についての検討
}

○南 修司郎 ${ }^{1)}$ 、松永達雄 ${ }^{2)} 、$ 藤井正人 ${ }^{2)}$ 、加我君孝 ${ }^{233}$

国立病院機構東京医療センター 耳鼻咽喉科1，国立病院機構東京医療センター 臨床研究センター2)、

国際医療福祉大学三田病院 耳鼻咽喉科 ${ }^{3}$

コネキシン 26 蛋白をコードする GJB2 遺伝子変異は最も多い非症候性劣性遺伝性難聴の原因であり、その難聴の程度は軽 度から重度まで幅広い。当施設で直接シークエンス法にて解析し、GJB2 病的遺伝子変異を両アレル持つ日本人遺伝性難聴 者126名の遺伝子型／表現型について検討を行った。16の GJB2 病的遺伝子変異が同定され、両アレルに inactivating 変異を もつ I / I 型 $(73 \%) 、$ 両アレルに non-inactivating 変異をもつ NI/NI 型（８％)、inactivating と non-inactivating のコンパ ウンドへテロ接合変異をもつ I/NI 型（19\%）の3つに分けられた。 I / I 型と I/NI 型では高度〜重度難聴がそれぞれ76\% と79\%、NI/NI 型では $80 \%$ が軽度〜中等度難聴であり、NI/NI 型は有意に難聴の程度が軽かった。NI/NI 型でのコネキシン 26蛋白立体構造情報からの考察も加え報告する。

\section{Usher 症候群の臨床的タイプ分類の問題点と課題}

○岩崎 聡1)、吉村豪兼 ${ }^{22}$ 、工 穣(12)、宇佐美真 ${ }^{21}$

信州大学 医学部 附属病院 人工聴覚器学講座、信州大学 医学部 耳鼻咽喉科 ${ }^{2}$

14 施設による多施設共同研究で、平成 22 年 11 月から平成 23 年 8 月までの 10 月間で Usher 症候群と臨床診断された 26 症 例（男性12名、女性14名）を対象とした。検查の実施率は純音聴力検査と遺伝子検查は $100 \%$ あ゙ったが、語音聴力検查・ $\mathrm{OAE}$ ・眼振検查・眼科検查が60 70\%、平衡機能検查であるカロリック検査（50\%）と重心動摇検査（30\%）の実施率は 低かった。タイプ1が10例（38.5\%)、タイプ 2 が 6 例（23.1\%)、タイプ 3が10例（38.5\%）であった。今回收集できたデ ータからタイプ分類を典型例と非典型例に分けると、規定が割合はっきりしているタイプ 1（70\%)、タイプ $2 （ 83.3 \%)$ は非典型例が多かったのに対し、曖昧な表現のタイプ 3 （90\%）は典型例が多かった。Usher 症候群は臨床症状に多様性が あるため施設によってはタイプ分類が異なることがあり得る。統一したタイプ分類の実施を目的に「Usher 症候群タイプ分 類のためのフローチャート」を作成した。

\section{2 当院耳鳴難聴外来における TRT 単独症例（TCI 使用者）の長期経過について}

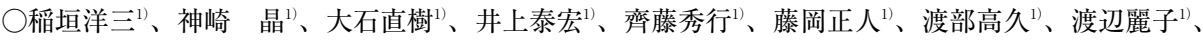

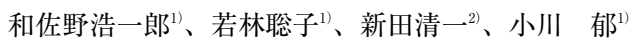 \\ 慶應義塾大学 医学部 耳鼻咽喉科 ${ }^{12}$ 、済生会宇都宮病院 耳鼻咽喉科 ${ }^{2}$
}

耳鳴の治療戦略として、「神経生理学的モデル」に立脚した、指示性カウンセリングと音響療法とを組み合わせて行う Tinnitus Retraining Therapy(TRT) が普及しつつある。2 年で効果が安定するとされているものの、国内外でもその後の長 期経過の報告は少ない。今回われわれはTRTの音響療法においてサウンドジェネレーター・Tinnitus Control Instrument （TCI）を用いたTRT 単独症例を対象にその経過をまとめた。対象は、2005年 3 月から2008年 4 月に慢性耳鳴にて慶応義塾 大学病院耳鼻咽喉科、耳鳴難聴外来を受診し、TRT 単独にて治療を継続した 107 症例のうち 2 年以上経過を追跡しえた 38 例。THI(Tinnitus Handicap Inventory) - 25：耳鳴りの日常生活への支障度に対する質問紙、の経時的変化抢よび外来通院 期間、終了契機を追跡した。個々の症例によって THI の推移および外来終了の契機が異なることから、単一的に 2 年で外 来フォローを中止することには注意を要するとともに、外来において患者個々に応じて検討する必要があると考える。 